\title{
Article \\ Examining the Importance of Green Food in the Restaurant Industry: Focusing on Behavioral Intentions to Eat Insects
}

\author{
Jinsoo Hwang ${ }^{1(\mathbb{D}}$ and Hyunjoon Kim ${ }^{2, *(\mathbb{D})}$ \\ 1 Department of Food Service, The College of Hospitality and Tourism Management, Sejong University, \\ Seoul 143-747, Korea; jhwang@sejong.ac.kr \\ 2 The Department of Tourism Management, The College of Business Administration, Dong-A University, \\ Busan 49236, Korea \\ * Correspondence: hyunjoon@dau.ac.kr
}

Citation: Hwang, J.; Kim, $\mathrm{H}$

Examining the Importance of Green Food in the Restaurant Industry: Focusing on Behavioral Intentions to Eat Insects. Int. J. Environ. Res. Public Health 2021, 18, 1905. https:// doi.org/10.3390/ijerph18041905

Academic Editor: Eliana Pereira

Received: 26 January 2021

Accepted: 13 February 2021

Published: 16 February 2021

Publisher's Note: MDPI stays neutral with regard to jurisdictional claims in published maps and institutional affiliations.

Copyright: (c) 2021 by the authors. Licensee MDPI, Basel, Switzerland. This article is an open access article distributed under the terms and conditions of the Creative Commons Attribution (CC BY) license (https:// creativecommons.org/licenses/by/ $4.0 /)$.

\begin{abstract}
This study analyzed the psychological benefits of environmentally friendly edible insect restaurants, by proposing that three subdimensions of psychological benefits positively affect attitude. Attitude was hypothesized to play an important role in the formation of desire and two subdimensions of behavioral intentions: intentions to use and willingness to pay more. A research model was verified using responses from 419 respondents collected in Korea. Data analysis indicated that (1) warm glow, (2) self-expressive benefits, and (3) nature experiences form attitude and that attitude helps to increase desire, which in turn positively enhances behavioral intentions. The data analysis results supported the importance of the psychological benefits of environmentally friendly edible insect restaurants.
\end{abstract}

Keywords: edible insect restaurants (EIRs); environmentally friendly; psychological benefits (PBs); attitude; behavioral intentions

\section{Introduction}

Globally, the damage caused by environmental pollution is serious. Environmental pollution results in global warming, which is when the average temperature of the Earth rises rapidly due to greenhouse gases in the atmosphere [1]. In particular, global warming is a major cause of abnormal climate changes, such as droughts, floods, and desertification $[2,3]$. For this reason, consumers have become more aware of environmental pollution, which leads to changes in their consumption behaviors [4,5]. For example, consumers want to buy ecofriendly products to protect our environment, and they are even willing to pay more for such products [6,7]. In order to meet consumers' environmental needs, companies are also making many efforts to implement environmental management $[8,9]$.

Recently, environmental protection has become an important issue in the restaurant industry, and many scholars and practitioners are paying attention to the environmentally friendly role of edible insect restaurants (hereafter EIRs). For example, edible insects aid recycling of animal waste and further reduce greenhouse gas emissions [10,11]. In addition, many restaurant managers and chefs are working hard to develop new menus using edible insects to create new customers [12]. The report "Edible Insects: Future Prospects for Food and Feed Security" released by the Food and Agriculture Organization of the United Nation in 2013 also indicated that edible insects (hereafter EI) are sustainable foodstuff for the future. As such, people are getting more and more interested an EI in the food service industry, but there is a lack of academic research.

More importantly, environmentally friendly services, such as EIRs, have a vital role to play in giving psychological benefits (hereafter PBs) to consumers [13,14]. PBs are feelings of trust in a certain thing or person that leads to peace of mind [15]. PBs have great meaning in green research because consumers are comfortable in thinking that they participate in the environmental movement by purchasing green products/services [16]. In the same vein, 
consumers are more likely to be mentally comforted that they can protect the environment by dining at environmentally friendly EIRs. For this reason, it is meaningful to examine the significant role of PBs in the field of EIRs.

In summary, this paper was designed to apply the concept of PBs to the context of EIRs using structural equation modeling (SEM) analysis for the first time. Specifically, the current paper examined (1) the effect of three subdimensions of PBs, namely, warm glow (hereafter WG), self-expressive benefits (hereafter SEBs), and nature experiences (NEs) on attitude, (2) the important role of attitude in the formation of desire and intentions to use and willingness to pay more, and (3) the influence of desire on intentions to use and willingness to pay more. The results of this study will provide important information for managers who currently operate or prepare EIRs to understand the importance of the ecofriendly role of EIRs and to establish marketing tactics to improve consumer behavioral intentions. In addition, the study, as shown below, consists of six sections: (1) Introduction, (2) Literature review, (3) Methodology, (4) Discussion and implications, (5) Conclusion, and (6) Limitations and future research.

\section{Literature Review}

\subsection{Edible Insect Restaurants and Their Ecofriendly Role}

According to Hwang and Choe [17], EIRs refer to "a commercial property serving customers a specialty cuisine consisting of EIs" (p. 1). Globally, the number of EIRs is on the rise [18]. For instance, among the diverse menus of EIRs in Thailand, insect salads made from eggs of water bugs and ants. In addition, tom yam soups based on silkworm pupae are popular [19]. In China, EI foods made from bamboo insects, grasshoppers, silkworm pupae, and stink bugs are loved by the Chinese [20]. In addition, The Fonda Don Bon Restaurant in Mexico City is popular, with EI meals made from ant larvae, grasshoppers, and maggy worms, which are sold at about $25 \$$ US [21].

The popularity of EIRs results from many of the advantages of eating EIs. More than two billion people in the world are estimated to consume insects as a regular part of their diet [18], and the estimated global market volume of EI will be US $\$ 8$ billion by 2030 [22]. Approximately 1900 species have been identified as EIs across different continents [23]. Crickets, mealworms, buffalo worms, grasshoppers, ants, silkworms, and cicadas are examples of commonly consumed insects by people [18]. Crickets are loved as they provide excellent crunchy flavor and are rich in protein and amino acids that easily break down in the human digestive system. Grasshoppers are particularly well known as chapulines in Mexican cuisine, and are simmered in mole sauce or tossed into tacos. Calories from EIs run to $776.9 \mathrm{kcal}$ per $100 \mathrm{~g}$ which is superior to that from soy, and the composition of six fatty acids and unsaturated omega- 3 in mealworms is higher than that in beef or pork [24].

More importantly, the environmental aspects of EIs have consistently attracted great attention (e.g., $[18,25,26])$. The livestock production systems are known to adversely affect the environment [17]. Extensive land is needed to raise livestock, which leads to deforestation and desertification [27]. Furthermore, livestock emit greenhouse gas emissions that have a serious impact on climate change. Such climate change brings great problems to human food production [28]. On the other hand, EIs require far less feed than livestock, and the ammonia emissions of EIs are also very low [29]. Global warming potential levels are also the lowest in EIs compared to animals like beef and chicken [30].

In summary, livestock breeding has a major impact on the destruction of the global environment, such as global warming and desertification. Therefore, EIs are gaining attention as an alternative source of food, but there is a lack of research on EIs in the restaurant industry.

\subsection{Psychological Benefits}

In consumer research, PBs refer to the mental stability that consumers perceive after purchasing a particular product/service [31]. In recent years, the concept of PBs has been 
widely used in green research explaining environmentally friendly behavior as consumers are concerned about environmental protection [16]. In other words, consumers want to use ecofriendly products or services because they are well aware that their ecofriendly consumption helps to protect the environment [14]. Prior studies have commonly suggested the following three subdimensions of PBs in green research: (1) WG, (2) SEBs, and (3) NEs (e.g., $[13,14,16,32,33])$.

The first dimension of PBs is WG, which is defined as "satisfaction that goes beyond the benefits derived from aggregate provision of a public good through proenvironmental behavior" [34] (p. 239). WG is a moral satisfaction with what has been done to protect the environment, so it is known as self-satisfaction with the moral responsibility for the actions taken to protect the environment $[35,36]$. Similarly, Harbaugh, Mayr, and Burghart [37] suggested that WG is a reward that humans gain from helping others. For this reason, WG is called 'intrinsic satisfaction' [38]. In addition, Brekke, Kverndokk, and Nyborg [39] examined the relationship between social responsibility and WG, and they found that the higher the level of the social responsibility, the higher WG.

The second dimension of PBs is SEBs. The concept of SEBs refers to the benefits consumers derive from their efforts to express concerns about natural environment problems to others $[32,40]$. SEBs are theoretically supported by signaling theory $[16,41,42]$, suggesting that humans tend to express their likes and dislikes for any phenomenon or thing based on their beliefs. Green consumer behavior can be explained by self-expressive benefit. Green consumers are interested in protecting the environment, so they want to buy green products to express it, which consequently leads to high levels of SEBs [43]. Hu [44] also argued that people have a higher level of SEBs when they express interest in protecting the natural environment.

The third dimension of PBs is NEs. Nature means a lot in our lives. In philosophy, nature is the foundation of our lives [45], so they are inextricably linked. In particular, our mental health is greatly helped by contact with nature, such as mountains, rivers and lakes, which enhances the well-being perception $[46,47]$. NEs serve to stimulate ecofriendly consumer purchases $[14,48]$. For example, when a company promotes products to consumers with higher levels of NEs through ads that emphasize the natural environment, the advertising effect is greater than those with lower levels of NEs.

\subsection{Effect of Psychological Benefits on Attitude}

This study firstly hypothesized the effect of PBs of EIRs on attitude towards using EIRs based on the following the rationale. Attitude refers to "the degree to which a person has a favorable or unfavorable evaluation or appraisal of the behavior" [49] (p. 188). Many prior studies have long examined the important role of attitude in consumer research, and they found that it is a significant factor influencing individuals' decision making process for purchase (e.g., [50-52]).

It is widely accepted that customers have a positive attitude toward using a certain product when they are comforted with the use of the product that can show their proenvironmental beliefs [13], suggesting that PBs are a critical factor affecting attitude. Furthermore, empirical research has also shown that PBs are an important predictor of attitude. For instance, $\mathrm{Hu}$ [44] argued that when consumers receive PBs from a certain product, they have positive feelings about using it. In addition, Hwang and Choi [32] showed that when customers receive high levels of PBs, including WG, SEBs, and NEs from green airline brands, they tend to have a positive image of the brands. More recently, Hwang et al. [16] also showed that if consumers have high levels of WG, SEBs, and NEs when they will have a good feeling. Based on this discussion, this study proposed the following hypotheses.

Hypothesis 1 (H1). Warm glow positively affects attitude.

Hypothesis 2 (H2). Self-expressive benefits positively affect attitude. 
Hypothesis 3 (H3). Nature experiences positively affect attitude.

\subsection{Effect of Attitude on Desire and Behavioral Intentions}

Since desire was introduced by the model of goal-directed behavior (also known as MGB), it has been applied in various fields, including bicycle travel, casino, cruise, and festival, [53-56]. Desire refers to "a state of mind whereby an agent has a personal motivation to perform an action or to achieve a goal" [57] (p. 71). People's desire is a state in which they crave specific actions which are mainly formed through internal stimuli such as past experiences $[57,58]$. For instance, if consumers have a good experience with any product, they will have high a level of desire to use the product.

According to MGB, consumers are more likely to desire to use a certain product if they have a positive attitude towards the product [58], suggesting that attitude is a significant predictor of desire. Previous research has also supported the relationship between two concepts. For example, Han, Kim, and Lee [6] examined the relationship between attitude and desire in the context of an environmentally responsible museum. They argued that attitude is a significant factor affecting desire. More recently, Hwang and Lyu [59] investigated the influence of attitude on desire in the airline industry, and they found that when passengers have a favorable attitude towards using an environmentally friendly airline, they are more likely to have high levels of desire to use the airline. Thus, this study proposed the following hypothesis.

Hypothesis 4 (H4). Attitude has a positive influence on desire.

In addition, the current study proposed the influence of attitude on behavioral intentions. According to Oliver [60], behavioral intentions refer to "a stated likelihood to engage in a behavior" (p. 28). It is widely accepted that behavioral intentions have the following two subdimensions: intentions to use and willingness to pay more [61-63]. Intentions to use can be defined as "the degree to which a person has formulated conscious plans to perform or not perform some specified future behavior" [64] (p. 214). Since intentions to use are created according to the evaluation after using a product, people with high levels of intentions to use tend to show actual consumption [65]. Second, willingness to pay more can be defined as the amount people are willing to pay for their preferred brand over other comparable brands $[66,67]$. Willingness to pay more has a great meaning in ecofriendly management because consumers want to buy ecofriendly products to protect the environment, despite being more expensive than general products $[68,69]$.

There are many theoretical bases, such as the theories of planned behavior, of reasoned action, and of repurchase decision-making, for the relationship between attitude and behavioral intentions $[50,70,71]$. These theories suggested that consumers' behavioral intentions toward a product depend on the attitude that the consumers have toward the product. Many studies have also found the relationship between attitude and behavioral intentions. For instance, Han and Hyun [72] developed a theoretical model to identify the effect of attitude on behavioral intentions in the field of an environmentally responsible museum. They found that attitude plays a critical role in creating behavioral intentions. In addition, Kim and Hwang [73] explored the relationship between attitude and behavioral intention among 401 potential consumers in the context of food deliver services using drones. They suggested that attitude positively affects behavioral intentions.

Hypothesis 5 (H5). Attitude positively affects intentions to use.

Hypothesis 6 (H6). Attitude positively affects willingness to pay more.

\subsection{Effect of Desire on Behavioral Intentions}

The relationship between desire and behavioral intention is theoretically supported by the MGB [74], suggesting that if people have a high level of desire to engage in a particular action, they are more likely to take the action. The attention, interest, desire, and actions 
model also theoretically supported the relationship between desire and behavioral intentions [75], indicating that desire is a significant antecedent of behavioral intentions. Prior research has shown the effect of desire on behavioral intentions. For instance, Meng and Han [56] investigated the role of desire in forming behavioral intentions using 394 bicycle tourists. They showed that when tourists desire to take a bicycle trip, they have high levels of behavioral intention. Lee et al. [76] also investigated the relationship between desire and behavioral intentions using 529 tourists in the context of pop-culture-featured destinations. They suggested that desire is a critical factor influencing behavioral intentions.

Hypothesis 7 (H7). Desire positively affects intentions to use.

Hypothesis 8 (H8). Desire positively affects willingness to pay more.

\subsection{Proposed Model}

Based on these eight hypotheses, the research model is suggested (see Figure 1).

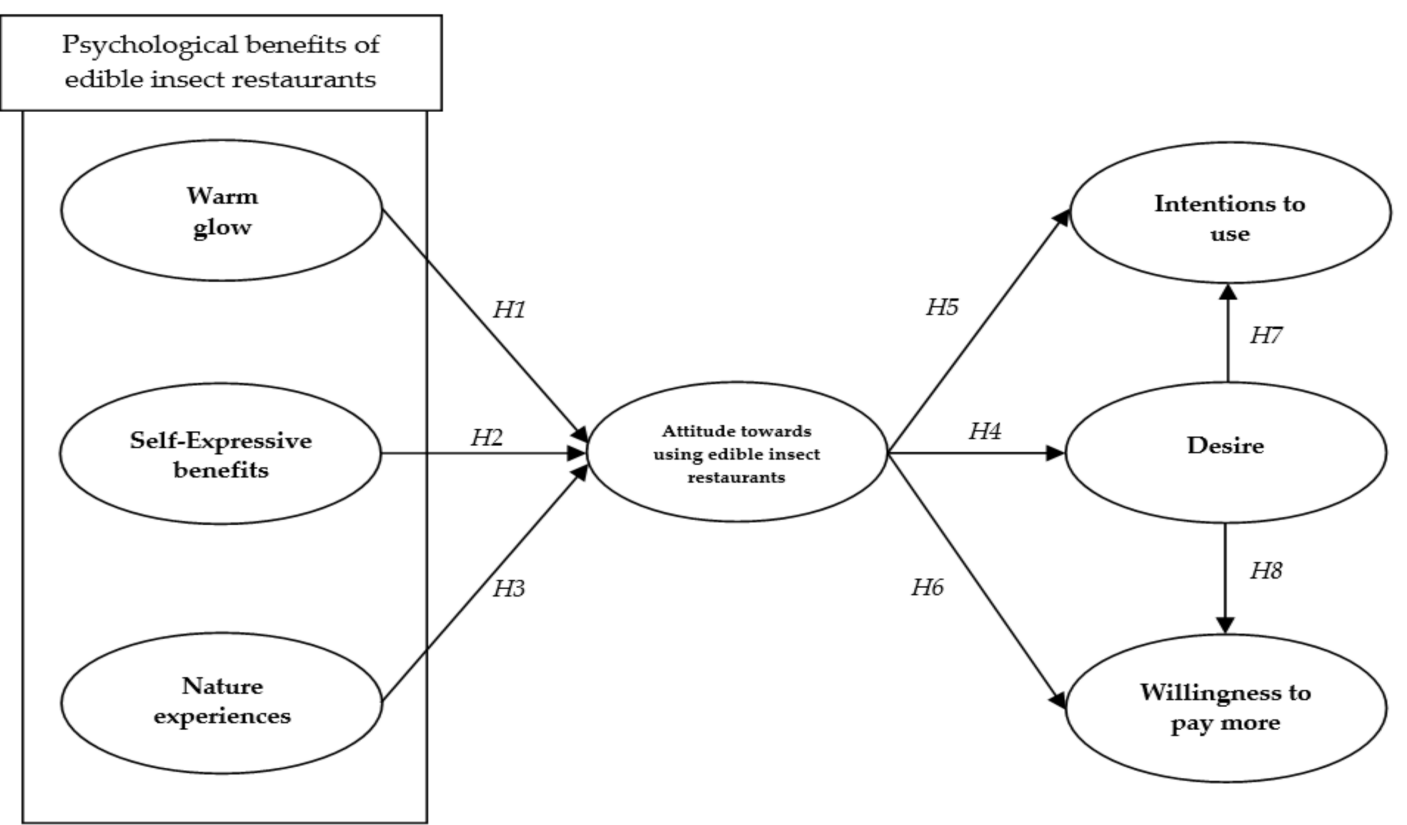

Figure 1. The proposed conceptual model.

\section{Methodology}

\subsection{Measurement Items}

Measurements of seven constructs were adapted from previous studies and revised to fit the context of ecofriendly EIRs. First, PBs consisted of three subdimensions, namely WG, SEBs, and NEs, which were measured with nine items employed by Hartmann and Apaolaza-Ibáñez [14], Hwang and Choi [32], and Hwang et al. [16]. Second, the concept of attitude was measured based on the three items cited from Ajzen [49] and Han and Hyun [72]. Third, behavioral intentions comprised two subdimensions, namely (1) intentions to use and (2) willingness to pay more, which were measured with six items adapted from Hwang and Hyun [52] and Zeithaml, Berry, and Parasuraman [77].

In addition, a seven-point Likert-type, ranging from 1 (strongly disagree) to 7 (strongly agree) was used to measure the seven constructs. In order to identify content validity, three expert groups were invited to review the initial questionnaire. The three expert groups consisted of professors majoring in restaurant management, master's and PhD students with experience working in the restaurant industry, and managers currently working in the 
restaurant industry. The review of the expert groups confirmed that the content validity of the questionnaire was not a problem.

\subsection{Data Collection}

Since there are not many EIRs in Korea, the respondents did not have a good understanding of such restaurants, so we showed two newspaper articles and one video explaining the environmental role of EIRs to the respondents. The study conducted a pretest based on 30 restaurant patrons using an online survey, and the results showed that the Cronbach alpha values of all measurement items exceeded 0.7 , ensuring the reliability of the measurements [78]. For the main data collection, we used the ' $E$ ' company, which is one of the largest online survey companies in Korea. In the same way as the pretest, we showed respondents two newspaper articles and one video before starting the survey. The company sent invitation emails to 6479 panels, of whom 450 completed the survey. However, 31 outliers were deleted. As a result, statistical analysis was performed based on 419 responses. In order to test proposed hypotheses, this study used confirmatory factor and structural equation modeling analyses based on the Analysis of Moment Structures (AMOS) program.

\subsection{Profile of Respondents}

Table 1 provides the profile of the respondents. The 419 respondents consisted of 211 males $(50.4 \%)$ and 208 females (49.6\%). The mean age of respondents was 37.95 years. With regard to monthly household income, 122 respondents $(29.1 \%)$ answered that their income was between 1001\$ US and 2000\$ US. In addition, about half of respondents $(n=218,52 \%)$ were married. Lastly, in terms of education level, $54.4 \%(n=228)$ held a bachelor's degree.

Table 1. Profile of survey respondents $(n=419)$.

\begin{tabular}{ccc}
\hline Variable & $n$ & Percentage \\
\hline Gender & 211 & 50.4 \\
Male & 208 & 49.6 \\
Female & & \\
Monthly household income & 14 & 3.3 \\
6001\$ US and over & 22 & 5.3 \\
5001\$ US-6000\$ US & 42 & 10.0 \\
4001\$ US-5000\$ US & 57 & 13.6 \\
3001\$ US-4000\$ US & 116 & 27.7 \\
2001\$ US-3000\$ US & 122 & 29.1 \\
1001\$ US-2000\$ US & 46 & 11.0 \\
Under 1000\$ US & 196 & 46.8 \\
Marital status & 218 & 52.0 \\
Single & 5 & 1.2 \\
Married & & \\
Widowed/Divorced & 61 & 14.6 \\
Education level & 78 & 18.6 \\
Less than High school & 228 & 54.4 \\
diploma & 52 & 12.4 \\
Associate's degree & & \\
Bachelor's degree & & \\
Graduate degree & & \\
Mean age = 37.95 years old & &
\end{tabular}

\subsection{Confirmatory Factor Analysis (CFA)}

Table 2 shows the results of CFA. The results indicated that the proposed model had an acceptable fit to the data including normed fit index (NFI), comparative fit index (CFI), Tucker-Lewis index (TLI), and root mean square error of approximation (RMSEA) [79]. The values of all the factor loadings were higher than 0.871 and were all significant $(p>0.001)$. 
Table 2. Confirmatory factor analysis: items and loadings.

\begin{tabular}{|c|c|}
\hline Construct and Scale Items & $\begin{array}{l}\text { Standardized } \\
\text { Loading }^{\text {a }}\end{array}$ \\
\hline \multicolumn{2}{|l|}{$\begin{array}{l}\text { Psychological benefits } \\
\text { Warm glow }\end{array}$} \\
\hline $\begin{array}{l}\text { With edible insect restaurants, I can feel good } \\
\text { because the restaurant helps to protect the environment. }\end{array}$ & 0.871 \\
\hline $\begin{array}{l}\text { With edible insect restaurants, I have the feeling of } \\
\text { contributing to the well-being of humanity and nature. }\end{array}$ & 0.909 \\
\hline $\begin{array}{l}\text { With edible insect restaurants, I can feel better } \\
\text { because the restaurant doesn't harm the environment. } \\
\text { Self-expressive benefits }\end{array}$ & 0.937 \\
\hline With edible insect restaurants, I can express my environmental concern. & 0.907 \\
\hline $\begin{array}{l}\text { With edible insect restaurants, I can demonstrate to myself and } \\
\text { my friends that I care about environmental conservation. }\end{array}$ & 0.941 \\
\hline $\begin{array}{l}\text { With edible insect restaurants, I can demonstrate to myself and } \\
\text { my friends that I care about environmental conservation. } \\
\text { Nature experiences }\end{array}$ & 0.928 \\
\hline Edible insect restaurants can make me feel close to nature. & 0.903 \\
\hline Edible insect restaurants can make me think of nature, fields, forests and mountains. & 0.941 \\
\hline $\begin{array}{c}\text { Edible insect restaurants can evoke the sensation of being in nature. } \\
\text { Attitude }\end{array}$ & 0.935 \\
\hline Unfavorable-favorable & 0.915 \\
\hline Bad-good & 0.899 \\
\hline Negative-positive & 0.944 \\
\hline Desires & \\
\hline I desire to use edible insect restaurants. & 0.930 \\
\hline My desire of using edible insect restaurants is strong. & 0.972 \\
\hline $\begin{array}{l}\text { I want to use edible insect restaurants. } \\
\text { Intentions to use }\end{array}$ & 0.963 \\
\hline I will dine out at edible insect restaurants. & 0.954 \\
\hline I am willing to dine out at edible insect restaurants. & 0.958 \\
\hline $\begin{array}{l}\text { I am likely to dine out at edible insect restaurants. } \\
\text { Willingness to pay more }\end{array}$ & 0.964 \\
\hline I am likely to pay more for dining out at edible insect restaurants. & 0.945 \\
\hline It is acceptable to pay more for dining out at edible insect restaurants. & 0.969 \\
\hline I am likely to spend extra in order to dine out at edible insect restaurants. & 0.965 \\
\hline
\end{tabular}

Goodness-of-fit statistics: $\chi^{2}=502.646, \mathrm{df}=168, \chi^{2} / \mathrm{df}=2.992, p<0.001, \mathrm{NFI}=0.961, \mathrm{CFI}=0.974, \mathrm{TLI}=0.967$, and RMSEA = 0.069

Notes 1: ${ }^{a}$ All factors loadings are significant at $p<0.001$. Notes 2: NFI $=$ normed fit index, CFI $=$ comparative fit index, TLI $=$ Tucker-Lewis index, and RMSEA = root mean square error of approximation.

As shown in Table 3, all of the composite reliability values were greater than the minimum threshold of 0.70 [80], which suggested that the measurement items had high levels of internal consistency. In addition, convergent validity was verified as all of the average variance extracted (AVE) values exceeded 0.50 [81]. Lastly, the AVE values were greater than the squared correlations between constructs, which indicated high levels of discriminant validity [80].

Table 3. Descriptive statistics and associated measures.

\begin{tabular}{|c|c|c|c|c|c|c|c|c|c|c|}
\hline & $\begin{array}{l}\text { No. of } \\
\text { Items }\end{array}$ & Mean (SD) & AVE & (1) & (2) & (3) & (4) & (5) & (6) & (7) \\
\hline (1) Warm glow & 3 & $4.11(1.24)$ & 0.821 & $0.932^{\mathrm{a}}$ & $0.806^{\mathrm{b}}$ & 0.702 & 0.703 & 0.714 & 0.707 & 0.589 \\
\hline (2) Self-expressive benefits & 3 & $3.79(1.26)$ & 0.856 & $0.650^{c}$ & 0.947 & 0.775 & 0.672 & 0.662 & 0.657 & 0.605 \\
\hline (3) Nature experiences & 3 & $3.59(1.35)$ & 0.858 & 0.493 & 0.601 & 0.948 & 0.622 & 0.632 & 0.637 & 0.314 \\
\hline (4) Attitude & 3 & $4.02(1.46)$ & 0.846 & 0.494 & 0.452 & 0.387 & 0.943 & 0.823 & 0.829 & 0.703 \\
\hline (5) Desire & 3 & $3.63(1.38)$ & 0.912 & 0.510 & 0.438 & 0.399 & 0.677 & 0.969 & 0.851 & 0.789 \\
\hline (6) Intentions to use & 3 & $3.64(1.39)$ & 0.919 & 0.500 & 0.432 & 0.406 & 0.687 & 0.724 & 0.971 & 0.824 \\
\hline (7) Willingness to pay more & 3 & $3.19(1.28)$ & 0.921 & 0.347 & 0.366 & 0.402 & 0.494 & 0.623 & 0.679 & 0.972 \\
\hline
\end{tabular}

Notes 1: $\mathrm{SD}=$ standard deviation and $\mathrm{AVE}=$ average variance extracted. Notes 2: a. Composite reliabilities are along the diagonal.

b. Correlations are above the diagonal. c. Squared correlations are below the diagonal. 


\subsection{Structural Equation Modeling (SEM)}

SEM analysis was conducted in order to identify the eight hypotheses. The structural model had an appropriate fit to the data [82]. The SEM analysis results revealed that all hypotheses were statistically supported at $p<0.05$. More specifically, the results indicated that WG $(\beta=0.435, p<0.05)$, SEBs $(\beta=0.193, p<0.05)$, and NEs $(\beta=0.190, p<0.05)$ positively affected attitude, which supports hypotheses 1,2 , and 3 . In addition, attitude plays an important role in the formation of desire $(\beta=839, p<0.05)$, intentions to use ( $\beta=152, p<0.05)$, and willingness to pay more $(\beta=172, p<0.05)$. Hence, hypotheses 4,5 and 6 were supported. Lastly, desire aided to increase intentions to use $(\beta=827, p<0.05)$, and willingness to pay more $(\beta=657, p<0.05)$. Thus, hypotheses 7 and 8 were supported. The results of SEM analysis are summarized in Table 4 and Figure 2.

Table 4. Standardized parameter estimates for the structural model.

\begin{tabular}{|c|c|c|c|c|c|}
\hline & & & Standardized Estimate & $t$-Value & Hypothesis \\
\hline H1 Warm glow & $\rightarrow$ & Attitude & 0.435 & $6.337 *$ & Supported \\
\hline H2 Self-expressive benefits & $\rightarrow$ & Attitude & 0.193 & $3.079 *$ & Supported \\
\hline H3 Nature experiences & $\rightarrow$ & Attitude & 0.190 & 2.484 * & Supported \\
\hline H4 Attitude & $\rightarrow$ & Desire & 0.839 & $22.541^{*}$ & Supported \\
\hline H5 Attitude & $\rightarrow$ & Intentions to use & 0.152 & $3.976 *$ & Supported \\
\hline H6 Attitude & $\rightarrow$ & Willingness to pay more & 0.172 & $2.669 *$ & Supported \\
\hline H7 Desire & $\rightarrow$ & Intentions to use & 0.827 & 19.838 * & Supported \\
\hline H8 Desire & $\rightarrow$ & Willingness to pay more & 0.657 & 10.125 * & Supported \\
\hline
\end{tabular}

Goodness-of-fit statistics: $\chi^{2}=608.395, \mathrm{df}=178, \chi^{2} / \mathrm{df}=3.418, p<0.001, \mathrm{NFI}=0.953, \mathrm{CFI}=0.966, \mathrm{TLI}=0.960$, and RMSEA = 0.076

Notes 1: ${ }^{*} p<0.05$. Notes 2: NFI = normed fit index, CFI = comparative fit index, TLI = Tucker-Lewis index, and RMSEA = root mean square error of approximation.

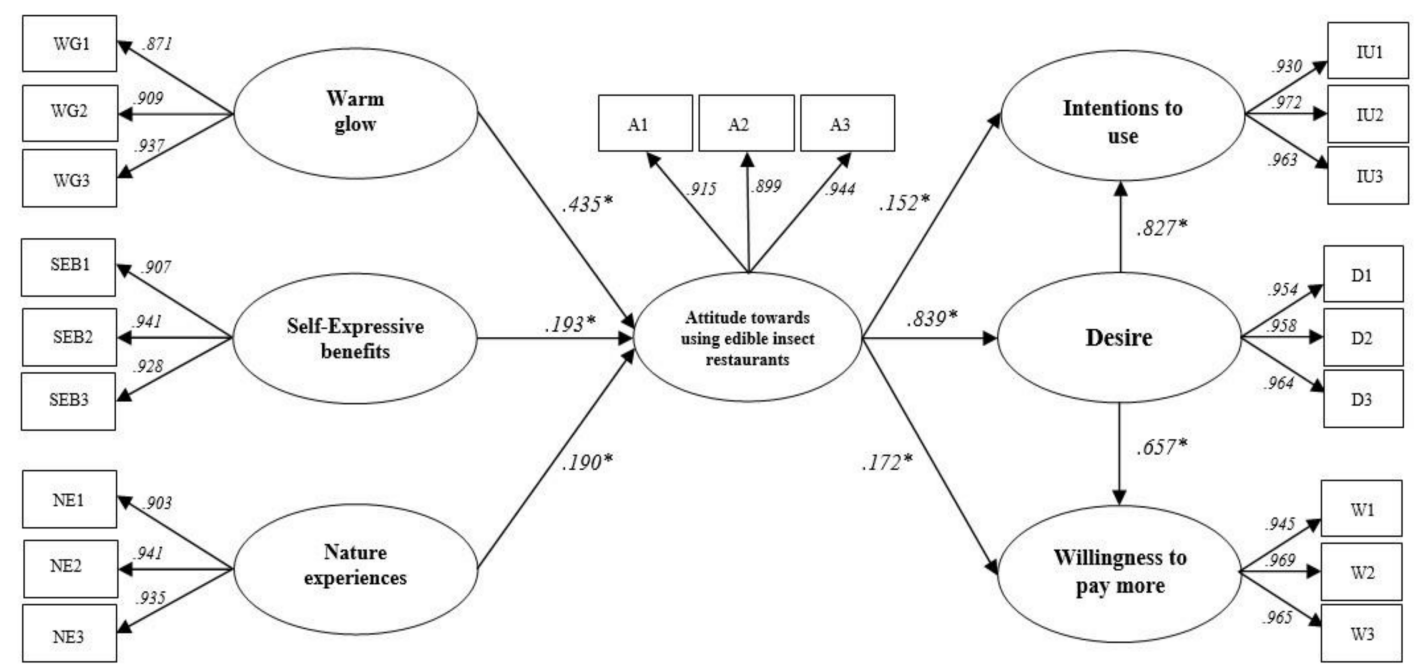

Figure 2. Standardized theoretical path coefficients. Note: ${ }^{*} p<0.05$

\section{Discussion and Implications}

\subsection{Theoretical Implications}

First, this study showed that WG is an important predictor of attitude, which suggested that consumers are more likely to have a positive attitude towards visiting EIRs when they feel that eating at the restaurants contributes to the well-being of humanity and nature. This finding indicated the importance of WG in green consumer behavior, which has been confirmed by previous studies in diverse fields $[16,32,40]$. They indicated that WG forms positive emotions or images about an object. For instance, Hwang and Choi [32] found that when passengers perceive high levels of WG, they tend to have a positive 
image. Unlike prior studies, the current study identified that WG is a vital factor in forming attitude in the context of EIRs for the first time, which is a critical theoretical implication of this paper.

Second, the current paper confirmed that SEBs are a crucial factor influencing attitude. The finding indicates that when people customers feel that they can show their concerns about the environment through visiting EIRs, they have a favorable attitude towards using the restaurants. The results of this paper are partially similar to prior studies in green research $[16,32,83]$, which suggested that SEBs are a significant predictor of attitude, emotion, and image. For instance, Ahmad and Thyagaraj [83] suggested that when customers have a high level of SEBs through a particular green brand, they tend to have a favorable attitude towards using the brand. Compared with prior research, the theoretical implication of this study is that it extended the concept of SEBs to the field of EIRs and found a new outcome variable of SEBs.

Third, the data analysis revealed that there is a positive relationship between NEs and attitude. In other words, if consumers perceive that EIRs make them feel close to natural environment including forests and mountains, they will have a positive attitude towards using the restaurants. Prior studies have also verified the relationship (e.g., [14,16,32]). For example, Hartmann and Apaolaza-Ibáñez [14] showed that when a certain green energy brand is reminiscent of being with NEs, consumers have a favorable attitude towards using the brand. In this respect, the current paper replicated and also further expanded the existing literature by finding the significance of NEs in the context of EIRs.

Fourth, another significant theoretical implication of this paper was to determine the role of attitude in the formation of three outcomes in the field of EIRs for the first time. To be specific, the SEM results indicated that attitude positively affects desire, which in turn positively affects intentions to use, and willingness to pay more. That is, when consumers have a favorable attitude towards visiting EIRs, they would desire to visit them and further to have high levels of intentions to use, and willingness to pay more. These findings are in line with existing studies (e.g., $[59,72,76])$, which indicated that attitude is an important factor influencing desire, intentions to use, and willingness to pay more. These findings have theoretical implications in that attitude was first introduced into the field of EIRs, thereby extending its applicability.

\subsection{Managerial Implications}

First, the data analysis result showed the effect of WG on attitude. This finding suggests the following important managerial implications. First and foremost, in order to make consumers' attitudes positive about visiting EIRs, it should be emphasized that the restaurants play an important role in protecting the environment. EIRs can contribute strongly to environmental protection in various aspects, such as greenhouse gas emissions and global warming [28,30]. More importantly, consumers are willing to purchase ecofriendly products to satisfy their environmental needs, despite costing more [84,85]. Therefore, restaurant companies operating or preparing EIRs need to explain the negative impacts of livestock on the environment. In addition, if consumers are well informed about the ecofriendly role of EIRs, they will have a good attitude towards using the restaurants. Especially in countries where there are few EIRs, such as Korea, consumers do not know the ecofriendly role of EIRs well, so more efforts are needed to inform the role.

Second, this study found a positive relationship between SEBs and attitude, which suggested that restaurant companies should enable consumers to express their concerns about their environment through visiting EIRs. Thus, EIRs should emphasize that consumers can participate in environmental protection campaigns by using their restaurants. In fact, a lot of restaurant companies are currently conducting an environmental protection campaign. For instance, Kentucky Fried Chicken (KFC) emphasizes that their business is sustainable by building LEED (Leadership in Energy and Environmental Design)-certified buildings, which leads to about 30 percent savings in energy and water use [86]. Subway is also promoting that they are ecofriendly by emphasizing that only vegetables supplied by 
farms that use ecofriendly measures are used as ingredients. Thus, if EIRs also emphasize through campaigns that such EIs are produced through environment-friendly measures, consumers will perceive that they can express their environmental concern with EIRs. Consequently, consumers will have a favorable attitude towards visiting EIRs.

Third, the current study found the effect of NEs on attitude in the context of EIRs. In other words, consumers think that they can experience nature through EIRs. It is recommended to produce advertisements that emphasize natural experiences. In fact, green advertising is known to have a critical impact on the consumer decision-making process $[87,88]$. Therefore, if EIRs appeal to consumers by creating an advertisement against the background of natural environment including forests and mountains, the consumers will recognize that they can experience nature with EIRs. In addition, it is recommended that the physical environment of EIRs creates a natural atmosphere so that customers can have NEs when they eat. As a result of such efforts, consumers are more likely to have a positive attitude toward using the restaurants.

\section{Conclusions}

The purpose of this research was to identify the environmentally friendly role of EIRs, focusing on the concept of PBs. More specifically, this study proposed a theoretical model with eight hypotheses based on the relationships among PBs, attitude, desire, and behavioral intentions. In order to test the proposed hypotheses, 419 responses were collected in Korea. The results of data analysis revealed that the three subdimensions of PBs, i.e., WG, SEBs, and NEs, help to increase attitude. In addition, attitude positively affected desire, which in turn had a positive influence on intentions to use and willingness to pay more.

\section{Limitations and Future Research}

Although this paper provides meaningful theoretical and managerial implications discussed above, the paper has the following limitations as well. First, the representativeness of the results of this study is an issue because the data for this paper were collected only in Korea. In particular, insect restaurants have not been activated in Korea, so future research is required to collect data from other countries where the restaurants are activated. Second, food culture varies regionally and internationally $[89,90]$. Thus, it is also meaningful to conduct comparative research on consumers in areas where EIRs are activated and areas where they are not. Third, this study collected data using an online survey, which leads to selection biases [91]; therefore, future research is necessary to employ different types of data collection methods. Fourth, the response rate of $6.94 \%$ in this study is somewhat low, so future research needs to consider different kinds of data collection methods in order to enhance response rate. Lastly, 419 samples were employed to assess eight hypotheses in the current study. Although Hair et al. [80] and Weston and Gore [92] suggested that a sample size of 200 is reasonable for performing CFA/SEM, future research is required to collect more data.

Author Contributions: Conceptualization, J.H. and H.K.; methodology, J.H.; software, J.H.; validation, J.H.; formal analysis, J.H.; investigation, H.K.; resources, H.K.; data curation, J.H.; writingoriginal draft preparation, J.H. and H.K.; writing - review and editing, J.H. and H.K. All authors have read and agreed to the published version of the manuscript.

Funding: This study is supported by a research grant from Dong-A University.

Institutional Review Board Statement: Not applicable.

Informed Consent Statement: Not applicable.

Data Availability Statement: Data sharing not applicable.

Conflicts of Interest: The authors declare no conflict of interest. 


\section{References}

1. Shine, K.P.; Fuglestvedt, J.S.; Hailemariam, K.; Stuber, N. Alternatives to the global warming potential for comparing climate impacts of emissions of greenhouse gases. Clim. Chang. 2005, 68, 281-302. [CrossRef]

2. Arnell, N.; Reynard, N. The effects of climate change due to global warming on river flows in Great Britain. J. Hydrol. 1996, 183, 397-424. [CrossRef]

3. Trenberth, K.E.; Dai, A.; Van Der Schrier, G.; Jones, P.D.; Barichivich, J.; Briffa, K.R.; Sheffield, J. Global warming and changes in drought. Nat. Clim. Chang. 2014, 4, 17-22. [CrossRef]

4. D'Souza, C.; Taghian, M. Green advertising effects on attitude and choice of advertising themes. Asia Pac. J. Mark. Logist. 2005, 17, 51-66. [CrossRef]

5. Laroche, M.; Bergeron, J.; Barbaro-Forleo, G. Targeting consumers who are willing to pay more for environmentally friendly products. J. Consum. Mark. 2001, 18, 503-520. [CrossRef]

6. Han, H.; Kim, W.; Lee, S. Stimulating visitors' goal-directed behavior for environmentally responsible museums: Testing the role of moderator variables. J. Destin. Mark. Manag. 2018, 8, 290-300. [CrossRef]

7. Liu, Y.; Yang, D.; Xu, H. Factors influencing consumer willingness to pay for low-carbon products: A simulation study in China. Bus. Strat. Environ. 2017, 26, 972-984. [CrossRef]

8. Molina-Azorín, J.F.; Tarí, J.J.; Pereira-Moliner, J.; López-Gamero, M.D.; Pertusa-Ortega, E.M. The effects of quality and envi-ronmental management on competitive advantage: A mixed methods study in the hotel industry. Tour. Manag. 2015, 50, 41-54.

9. Schaltegger, S.; Burritt, R.; Petersen, H. An Introduction to Corporate Environmental Management: Striving for Sustainability; Routledge: New York, NY, USA, 2017.

10. Megido, R.C.; Gierts, C.; Blecker, C.; Brostaux, Y.; Haubruge, É.; Alabi, T.; Francis, F. Consumer acceptance of insect-based alternative meat products in Western countries. Food Qual. Prefer. 2016, 52, 237-243. [CrossRef]

11. Van Huis, A. Edible insects contributing to food security? Agric. Food Secur. 2015, 4, 1-9. [CrossRef]

12. Halloran, A.; Flore, R.; Vantomme, P.; Roos, N. Edible Insects in Sustainable Food Systems; Springer: Cham, Switzerland, 2018.

13. Hartmann, P.; Apaolaza-Ibáñez, V. Virtual nature experiences as emotional benefits in green product consumption: The moderating role of environmental attitudes. Environ. Behav. 2008, 40, 818-842. [CrossRef]

14. Hartmann, P.; Apaolaza-Ibáñez, V. Consumer attitude and purchase intention toward green energy brands: The roles of psychological benefits and environmental concern. J. Bus. Res. 2012, 65, 1254-1263. [CrossRef]

15. Sweeney, J.C.; Webb, D.A. How functional, psychological, and social relationship benefits influence individual and firm commitment to the relationship. J. Bus. Ind. Mark. 2007, 22, 474-488. [CrossRef]

16. Hwang, J.; Cho, S.-B.; Kim, W. Consequences of psychological benefits of using eco-friendly services in the context of drone food delivery services. J. Travel Tour. Mark. 2019, 36, 835-846. [CrossRef]

17. Hwang, J.; Choe, J.Y. How to enhance the image of edible insect restaurants: Focusing on perceived risk theory. Int. J. Hosp. Manag. 2020, 87, 102464. [CrossRef]

18. Van Huis, A.; Van Itterbeeck, J.; Klunder, H.; Mertens, E.; Halloran, A.; Muir, G.; Vantomme, P. Edible Insects: Future Prospects for Food and Feed Security (No. 171); Food and Agriculture Organization of the United Nations: Rome, Italy, 2013.

19. Chen, P.P.; Jamyanya, T.; Rinderer, T.E.; Vongsamanode, S.; Matsuka, M.; Sylvester, H.A.; Oldroyd, B.P.; Wongsiri, S. Honey bees and other edible insects used as human food in Thailand. Am. Èntomol. 1998, 44, 24-29. [CrossRef]

20. Chen, X.; Feng, Y.; Chen, Z. Common edible insects and their utilization in China. Èntomol. Res. 2009, 39, 299-303. [CrossRef]

21. Bigurra, V. Fonda Don Chon: A Culinary Journey to Mexico's Past. Mexiconews, 13 April 2018. Available online: http://www. mexiconewsnetwork.com/en/news/gastronomy/fonda-don-chon-culinary-journey-mexico/(accessed on 30 June 2019 ).

22. Business Insider. Eating Insects Will soon Go Mainstream as Bug Protein is Set to Explode into an $\$ 8$ Billion Business. Available online: https: / /www.businessinsider.com/eating-insects-set-to-become-8-billion-business-barclays-2019-6 (accessed on 1 June 2019).

23. Durst, P.B.; Shono, K. Edible forest insects: Exploring new horizons and traditional practices. In Forest Insects as Food: Humans Bite Back; Food and Agricultural Organization of the United Nations: Bangkok, Thailand, 2010; pp. 1-4.

24. Xiaoming, C.; Ying, F.; Hong, Z.; Zhiyong, C. Review of the nutritive value of edible insects. In Forest Insects as Food: Humans Bite Back; Food and Agricultural Organization of the United Nations: Bangkok, Thailand, 2010; pp. 85-104.

25. Ramos-Elorduy, J. Anthropo-entomophagy: Cultures, evolution and sustainability. Ėntomol. Res. 2009, 39, 271-288. [CrossRef]

26. Yi, L.; Lakemond, C.M.; Sagis, L.M.; Eisner-Schadler, V.; van Huis, A.; van Boekel, M.A. Extraction and characterisation of protein fractions from five insect species. Food Chem. 2013, 141, 3341-3348. [CrossRef]

27. Norris, K.; Potts, S.G.; Mortimer, S.R. Ecosystem Services and Food Production. Issues Environ. Sci. Technol. 2010, 30, 52-69. [CrossRef]

28. Gamborg, C.; Röcklinsberg, H.; Gjerris, M. Sustainable proteins? Values related to insects in food systems. In Edible Insects in Sustainable Food Systems; Halloran, A., Flore, R., Vantomme, P., Roos, N., Eds.; Springer: Cham, Switzerland, 2018 ; pp. $199-211$.

29. Halloran, A.; Hanboonsong, Y.; Roos, N.; Bruun, S. Life cycle assessment of cricket farming in north-eastern Thailand. J. Clean. Prod. 2017, 156, 83-94. [CrossRef]

30. Makkar, H.P.; Tran, G.; Heuzé, V.; Ankers, P. State-of-the-art on use of insects as animal feed. Anim. Feed Sci. Technol. 2014, 197, 1-33. [CrossRef]

31. Gwinner, K.P.; Gremler, D.D.; Bitner, M.J. Relational benefits in services industries: The customer's perspective. J. Acad. Mark. Sci. 1998, 26, 101-114. [CrossRef] 
32. Hwang, J.; Choi, J.K. An investigation of passengers' psychological benefits from green brands in an environmentally friendly airline context: The moderating role of gender. Sustainability 2018, 10, 80. [CrossRef]

33. Lin, J.; Lobo, A.; Leckie, C. Green brand benefits and their influence on brand loyalty. Mark. Intell. Plan. 2017, 35, 425-440. [CrossRef]

34. Clark, C.F.; Kotchen, M.J.; Moore, M.R. Internal and external influences on pro-environmental behavior: Participation in a green electricity program. J. Environ. Psychol. 2003, 23, 237-246. [CrossRef]

35. Ma, C.; Burton, M. Warm glow from green power: Evidence from Australian electricity consumers. J. Environ. Econ. Manag. 2016, 78, 106-120. [CrossRef]

36. Menges, R.; Schroeder, C.; Traub, S. Altruism, warm glow and the willingness-to-donate for green electricity: An artefactual field experiment. Environ. Resour. Econ. 2005, 31, 431-458. [CrossRef]

37. Harbaugh, W.T.; Mayr, U.; Burghart, D.R. Neural Responses to taxation and voluntary giving reveal motives for charitable donations. Science 2007, 316, 1622-1625. [CrossRef]

38. De Young, R. Some psychological aspects of reduced consumption behavior: The role of intrinsic satisfaction and competence motivation. Environ. Behav. 1996, 28, 358-409. [CrossRef]

39. Brekke, K.A.; Kverndokk, S.; Nyborg, K. An economic model of moral motivation. J. Public Econ. 2003, 87, 1967-1983. [CrossRef]

40. Hartmann, P.; Apaolaza-Ibáñez, V. Green advertising revisited: Conditioning virtual nature experiences. Int. J. Advert. 2009, 28, 715-739. [CrossRef]

41. Aaker, J.L. The malleable self: The role of self-expression in persuasion. J. Mark. Res. 1999, 36, 45-57. [CrossRef]

42. Glazer, A.; Konrad, K.A. A signaling explanation for charity. Am. Econ. Rev. 1996, 86, 1019-1028.

43. Hartmann, P.; Ibáñez, V.A. Effects of green brand communication on brand associations and attitude. In International Advertising and Communication; Springer International Publishing: New York, NY, USA, 2006; pp. 217-236.

44. $\mathrm{Hu}, \mathrm{H} .-\mathrm{H}$. The effectiveness of environmental advertising in the hotel industry. Cornell Hosp. Q. 2012, 53, 154-164. [CrossRef]

45. Scharfstein, B.A. The Philosophers: Their Lives and the Nature of their Thought; Oxford University Press on Demand: Oxford, UK, 1989.

46. Leather, P.; Pyrgas, M.; Beale, D.; Lawrence, C. Windows in the workplace: Sunlight, view, and occupational stress. Environ. Behav. 1998, 30, 739-762. [CrossRef]

47. Maller, C.; Townsend, M.; Pryor, A.; Brown, P.; St Leger, L. Healthy nature healthy people: 'contact with nature'as an upstream health promotion intervention for populations. Health Promot. Int. 2006, 21, 45-54. [CrossRef] [PubMed]

48. Bögeholz, S. Nature experience and its importance for environmental knowledge, values and action: Recent German empirical contributions. Environ. Educ. Res. 2006, 12, 65-84. [CrossRef]

49. Ajzen, I. The theory of planned behavior. Organ. Behav. Hum. Decis. Process. 1991, 50, 179-211. [CrossRef]

50. Ajzen, I. From intentions to actions: A theory of Planned Behavior. In Action Control: From Cognition to Behavior; Kuhl, J., Beckmann, J., Eds.; Springer: Berlin/Heidelberg, Germany, 1985; pp. 11-39.

51. Ajzen, I.; Fishbein, M. Attitudes and the Attitude-Behavior Relation: Reasoned and Automatic Processes. Eur. Rev. Soc. Psychol. 2000, 11, 1-33. [CrossRef]

52. Hwang, J.; Hyun, S.S. First-class airline travelers' tendency to seek uniqueness: How does it influence their purchase of ex-pensive tickets? J. Travel Tour. Mark. 2017, 34, 935-947. [CrossRef]

53. Song, H.J.; Lee, C.K.; Kang, S.K.; Boo, S.J. The effect of environmentally friendly perceptions on festival visitors' decision-making process using an extended model of goal-directed behavior. Tour. Manag. 2012, 33, 1417-1428. [CrossRef]

54. Song, H.J.; Lee, C.K.; Norman, W.C.; Han, H. The role of responsible gambling strategy in forming behavioral intention: An application of a model of goal-directed behavior. J. Travel Res. 2012, 51, 512-523. [CrossRef]

55. Han, H.; Jae, M.; Hwang, J. Cruise travelers' environmentally responsible decision-making: An integrative framework of goal-directed behavior and norm activation process. Int. J. Hosp. Manag. 2016, 53, 94-105. [CrossRef]

56. Meng, B.; Han, H. Effect of environmental perceptions on bicycle travelers' decision-making process: Developing an extended model of goal-directed behavior. Asia Pac. J. Tour. Res. 2016, 21, 1184-1197. [CrossRef]

57. Perugini, M.; Bagozzi, R.P. The distinction between desires and intentions. Eur. J. Soc. Psychol. 2004, 34, 69-84. [CrossRef]

58. Leone, L.; Perugini, M.; Ercolani, A.P. Studying, practicing, and mastering: A test of the model of goal-directed behavior (MGB) in the software learning domain. J. Appl. Soc. Psychol. 2004, 34, 1945-1973. [CrossRef]

59. Hwang, J.; Lyu, S.O. Relationships among green image, consumer attitudes, desire, and customer citizenship behavior in the airline industry. Int. J. Sustain. Transp. 2019, 14, 437-447. [CrossRef]

60. Oliver, R.L. Satisfaction: A Behavioral Perspective on the Consumer; McGraw-Hill: New York, NY, USA, 1997.

61. Barber, N.; Kuo, P.; Bishop, M.; Goodman, R. Measuring psychographics to assess purchase intention and willingness to pay. J. Consum. Mark. 2012, 29, 280-292. [CrossRef]

62. Hwang, J.; Choe, J.Y. Exploring perceived risk in building successful drone food delivery services. Int. J. Contemp. Hosp. Manag. 2019, 31, 3249-3269. [CrossRef]

63. Luzar, E.; Cosse, K.J. Willingness to pay or intention to pay: The attitude-behavior relationship in contingent valuation. J. Soc. Econ. 1998, 27, 427-444. [CrossRef]

64. Warshaw, P.R.; Davis, F.D. Disentangling behavioral intention and behavioral expectation. J. Exp. Soc. Psychol. 1985, 21, 213-228. [CrossRef]

65. Han, H.; Meng, B.; Kim, W. Emerging bicycle tourism and the theory of planned behavior. J. Sustain. Tour. 2017, 25, 292-309. [CrossRef]

66. Kim, E.J.; Choi, C.; Tanford, S. Influence of scarcity on travel decisions and cognitive dissonance. Asia Pac. J. Tour. Res. 2020, 25, 721-735. [CrossRef] 
67. Netemeyer, R.G.; Krishnan, B.; Pullig, C.; Wang, G.; Yagci, M.; Dean, D.; Ricks, J.; Wirth, F. Developing and understanding price premium for grocery products validating measures of facets of customer-based brand equity. J. Bus. Res. 2004, 57, 209-224. [CrossRef]

68. Hwang, J.; Kim, H. Consequences of a green image of drone food delivery services: The moderating role of gender and age. Bus. Strat. Environ. 2019, 28, 872-884. [CrossRef]

69. Royne, M.B.; Levy, M.; Martinez, J. The public health implications of consumers' environmental concern and their willingness to pay for an eco-friendly product. J. Consum. Aff. 2011, 45, 329-343. [CrossRef]

70. Fishbein, M.; Ajzen, I. Belief, Attitude, Intention, and Behavior: An Introduction to Theory and Research; Adison-Wesley: Boston, MA, USA, 1975. [CrossRef]

71. Han, H.; Ryu, K. The theory of repurchase decision-making (TRD): Identifying the critical factors in the post-purchase deci-sionmaking process. Int. J. Hospitality Manag. 2012, 31, 786-797. [CrossRef]

72. Han, H.; Hyun, S.S. Key factors maximizing art museum visitors' satisfaction, commitment, and post-purchase intentions. Asia Pac. J. Tour. Res. 2017, 22, 834-849. [CrossRef]

73. Kim, J.J.; Hwang, J. Merging the norm activation model and the theory of planned behavior in the context of drone food de-livery services: Does the level of product knowledge really matter? J. Hosp. Tour. Manag. 2020, 42, 1-11. [CrossRef]

74. Perugini, M.; Bagozzi, R.P. The role of desires and anticipated emotions in goal-directed behaviours: Broadening and deepening the theory of planned behaviour. Br. J. Soc. Psychol. 2001, 40, 79-98. [CrossRef] [PubMed]

75. Hassan, S.; Nadzim, A.; Zaleha, S.; Shiratuddin, N. Strategic use of social media for small business based on the AIDA model. Procedia Soc. Behav. Sci. 2015, 172, 262-269. [CrossRef]

76. Lee, S.; Song, H.; Lee, C.-K.; Petrick, J.F. An integrated model of pop culture fans' travel decision-making processes. J. Travel Res. 2017, 57, 687-701. [CrossRef]

77. Zeithaml, V.A.; Berry, L.; Parasuraman, A. The behavioral consequences of service quality. J. Mark. 1996, 60, 31-46. [CrossRef]

78. Hundleby, J.D.; Bernstein, I.H. Psychometric Theory, 3rd ed.; McGraw-Hill: New York, NY, USA, 1994; ISBN 007047849X.

79. Byrne, B.M. Structural equation modeling with AMOS, EQS, and LISREL: Comparative Approaches to testing for the factorial validity of a measuring instrument. Int. J. Test. 2001, 1, 55-86. [CrossRef]

80. Hair, J.F., Jr.; Black, W.C.; Babin, B.J.; Anderson, R.E.; Tatham, R.L. Multivariate Data Analysis, 6th ed.; Prentice-Hall: Upper Saddle River, NJ, USA, 2006.

81. Fornell, C.; Larcker, D.F. Structural equation models with unobservable variables and measurement error: Algebra and statistics. J. Mark. Res. 1981, 18, 382-388. [CrossRef]

82. Singh, R. Does my structural model represent the real phenomenon?: A review of the appropriate use of Structural Equation Modelling (SEM) model fit indices. Mark. Rev. 2009, 9, 199-212. [CrossRef]

83. Ahmad, A.; Thyagaraj, K.S. Consumer's intention to purchase green brands: The Roles of environmental concern, environmental knowledge and self expressive benefits. Curr. World Environ. 2015, 10, 879-889. [CrossRef]

84. Han, H.; Hyun, S.S. Drivers of customer decision to visit an environmentally responsible museum: Merging the theory of planned behavior and norm activation theory. J. Travel Tour. Mark. 2017, 34, 1155-1168. [CrossRef]

85. Trang, H.L.T.; Lee, J.-S.; Han, H. How do green attributes elicit pro-environmental behaviors in guests? The case of green hotels in Vietnam. J. Travel Tour. Mark. 2019, 36, 14-28. [CrossRef]

86. Szalay, J. Restaurant tips for sustainable building. QSR Magazine, 1 January 2020. Available online: https://www.qsrmagazine. $\mathrm{com} /$ sustainability/restaurant-tips-sustainable-building(accessed on 1 January 2020).

87. Ankit, G.; Mayur, R. Green marketing: Impact of green advertising on consumer purchase intention. Adv. Manag. 2013, 6, 14.

88. Haytko, D.L.; Matulich, E. Green advertising and environmentally responsible consumer behaviors: Linkages examined. J. Manag. Mark. Res. 2008, 1, 2.

89. Prescott, J.; Bell, G. Cross-cultural determinants of food acceptability: Recent research on sensory perceptions and preferences. Trends Food Sci. Technol. 1995, 6, 201-205. [CrossRef]

90. Tu, V.P.; Valentin, D.; Husson, F.; Dacremont, C. Cultural differences in food description and preference: Contrasting Viet-namese and French panellists on soy yogurts. Food Qual. Prefer. 2010, 21, 602-610. [CrossRef]

91. Wright, K.B. Researching Internet-based populations: Advantages and disadvantages of online survey research, online questionnaire authoring software packages, and web survey services. J. Comput. Mediat. Commun. 2005, 10, JCMC1034.

92. Weston, R.; Gore, P.A. A brief guide to structural equation modeling. Couns. Psychol. 2006, 34, 719-751. [CrossRef] 